\title{
Reflections on the value of citizenship - explaining naturalisation practices
}

\author{
David Reichel ${ }^{1,}{ }^{*}$, Bernhard Perchinig² \\ 1 European Union Agency for Fundamental Rights, Vienna, Austria \\ 2 International Centre for Migration Policy Development, Vienna, Austria \\ * E-Mail: david.reichel@gmx.at
}

\begin{abstract}
The article raises the question of why immigrants become or do not become citizens of their destination country. Political incorporation of immigrants through naturalisation is driven by several factors, including opportunities to naturalise on the one hand and the (perceived) added value of naturalisation on the other hand. We argue that naturalisation propensities are strongly driven by policies, while settlement in a country raises the value of citizenship and leads to the acceptance of higher costs. Based on data from the Austrian Mikrozensus we examine the factors that drive citizenship status of immigrants from the main countries and regions of origin in Austria. We find that indicators related to the settlement of immigrants as well as indicators for having easier access to citizenship, most notably higher socio-economic resources, reduce the likelihood of being a foreign citizen.
\end{abstract}

\section{Keywords}

Naturalisation, citizenship, immigration, nationality, settlement

\section{Der Wert der Staatsbürgerschaft: Zur empirischen Erklärung von Einbürgerungspraxen}

\section{Zusammenfassung}

Der Beitrag beschäftigt sich mit der Frage, welche Faktoren die Einbürgerungswahrscheinlichkeit von ImmigrantInnen beeinflussen. Die politische Einbindung von ImmigrantInnen durch Einbürgerung wird einerseits durch die Möglichkeiten zur Einbürgerung und andererseits durch den (angenommenen) Mehrwert der Staatsbürgerschaft erklärt. Unser Hauptargument ist, dass Einbürgerungen stark durch die Einbürgerungspolitik, im Sinne von gesetzlichen Regelungen, bestimmt sind. Die Niederlassung in einem Land erhöht den Wert der Staatsbürgerschaft des Ziellandes und führt dadurch zur Akzeptanz von höheren Kosten. Wir untersuchen unseren theoretischen Rahmen mittels einer Analyse des österreichischen Mikrozensus. Es zeigt sich, dass Indikatoren für Niederlassung sowie Indikatoren für leichteren Zugang zur Staatsbürgerschaft, vor allem höherer sozio-ökonomischer Status, die Einbürgerungswahrscheinlichkeit erhöhen.

\section{Schlüsselwörter}

Einbürgerung, Staatsbürgerschaft, Einwanderung, Staatsangehörigkeit, Niederlassung

\section{Acknowledgment}

The authors would like to thank Rainer Bauböck, Joachim Blatter, Eva Østergaard-Nielsen and Maarten P. Vink for valuable comments on earlier versions of the paper and we are grateful for the comments by the two anonymous peer reviewers.

The opinions expressed in this article are those of the authors and neither represent the views of the European Union Agency for Fundamental Rights (FRA) nor of the International Centre for Migration Policy Development (ICMPD). This work was partly supported by the International Centre for Migration Policy Development (ICMPD), Vienna. 


\section{Introduction}

Why not? Why do some foreign immigrants not take up citizenship of their country of residence and remain foreigners in a country that became their home country for a long period of their lives? In many countries there are large proportions of immigrants, who do not naturalise and remain foreign citizens with limited rights and without access to suffrage.

In fact for a long time not much was known about factors driving people's decisions about citizenship acquisition, but research on the topic has risen considerably in the past decade. The main questions about the determinants of naturalisation are whether and to what extent persons cannot get naturalised and whether and to what extent persons do not want to get naturalised. These questions are closely interrelated since our desires are also influenced by what is possible and what is not, as has been argued by Pierre Bourdieu (1993, 97-I2I).

A survey in seven European countries recently found that most immigrants from third countries want to take up citizenship in their country of residence (Huddleston/ Tjaden 20I2), and many of them also do so. But there is still a considerable share of immigrants, who do not naturalise and the percentage of foreign citizens among immigrants varies considerably across countries (OECD 2OII; Reichel 2OI2).

In this paper we address the questions of why persons remain foreign citizens and try to explain factors driving naturalisation. We argue that naturalisation propensities are to a large extent driven by policies. We sketch the value of host country citizenship for immigrants as a function of costs and expected benefits, which are largely designed by policies. Whether or not a person acquires host countries citizenship is determined by whether or not the person is able to meet eligibility criteria and pay the costs of citizenship and to what extent the person thinks the benefits of acquiring new rights outweighs the costs (including potentially losing rights in the country of origin). Benefits do not only include citizenship rights, but also recognition as a full member of the polity (Bauböck 2007).

Austria - our case study - presents an extremely interesting case for studying citizenship acquisitions due to its high numbers of immigrants on the one side and its strict naturalisation policy on the other. Austria's long history of immigration makes it an important country of immigration with over 15 percent foreign born population, mostly coming from Germany, Turkey and former Yugoslavian countries. Austria's citizenship policy is marked by long waiting periods for naturalisation, which is in principle ten years of legal residence. Persons willing to naturalise have

I Certain groups of immigrants, such as EU nationals as well as refugees are allowed to apply for citizenship after six years of residence. Since 2013 all immigrants are allowed to apply for citizenship after six years, however, they have to proof particular 'integration', such as having worked as a volunteer for three years. to prove amongst others income above the poverty threshold over three years, lack of criminal records, they have to pass a German and citizenship test and pay a comparably large fee of around 800 to 2,000 Euros (Stern/Valchars 20I3). If possible, naturalisation candidates have to renounce their previous nationality in order to obtain Austrian citizenship. Naturalisation laws have changed frequently in the past two decades (Cinar/Waldrauch 2006).

The paper begins with outlining our theoretical considerations and hypotheses explaining the value of host country citizenship for immigrants. After that we present overview statistics and describe the data source used for the analysis. This section is followed by a presentation of the results of our logistic regression models and the last section concludes the paper.

\section{Theory and hypotheses}

The value of national citizenship for individuals is driven by opportunity structures designed by policy makers as well as the degree of their settlement in a country. While some legal constraints are reduced over time, most notably requested length of residence, some constraints remain, such as financial costs and sometimes proof of language skills. What people can gain from citizenship depends on their current legal status and the rights attached to their status. The more rights persons already possess in the country without having national citizenship, the lower the value added by acquiring citizenship of the host country. For persons with higher socio-economic status costs of naturalisation are 'lower' in relative terms (e.g. as percentage of their income), which reduces the burden of financial costs attached to naturalisation. At the same time, in case persons have to give up their previous citizenship, rights might be lost in their country of origin, which - depending on the intensity of the wish to return to this country or to live a transnational life in both countries - reduces the attractiveness of the new citizenship. This interplay between being an external citizen or a non-citizen and transnational life is outlined by Rainer Bauböck (2OI2) and also refers to the importance of length of residence in the process of settlement in a country. The decision to settle in a country is driven by a variety of reasons, including the family situation, most notably having children in the country of destination. Settlement decisions are also indicated by the housing situation, since persons deciding to settle in a country also invest more in their houses or dwellings. As an empirical study in Vienna has shown, the decision to invest into property often is the last trigger to decide for naturalisation (Kohlbacher/Reeger 2008). Moreover, other issues such as emo- 
tional attachments or identity questions might shape the decisions over citizenship.

We assume that there are two main spheres that influence the likelihood of a person's decision to naturalise in a country. Firstly and most obviously, legal constraints at destination countries strongly influence the opportunities to naturalise for foreign citizens (Reichel 20IIa; Dronkers/Vink 2012). Every country has a certain set of rules determining who will get access to citizenship and who is not allowed to become naturalised. The main conditions include length of residence, renunciation of former citizenship, criminal records, 'good character', financial and health requirements, language, country knowledge, value and integration requirements as well as procedural conditions for naturalisation, including administrative fees to be paid for naturalisation or the length and bureaucratic complexities of the process (for an overview of international analysis of naturalisation policies in Europe, see Bauböck et al. 2006; Vink/de Groot 20II; Goodman 20II). The most important regulations that hinder naturalisation are requirements to renounce citizenship (Reichel 20Ira), whereas the acceptance of dual citizenship increases naturalisation propensities (Mazzolari 2009). In order to have a positive effect on the naturalisation propensity, dual citizenship must be allowed in the country of origin and destination. In this way country of origin policies might also have an influence on naturalisation practices in countries of residence (Dronkers/ Vink 2012; Vink et al. 20I3). ${ }^{2}$

Secondly, migrant agency, and in particular the value attributed to naturalisation by migrants and migrants households motivate the decision making for or against naturalisation. In our understanding, these decisions are a part of migrants' agency shaping individual and household livelihood strategies. Modern migration theory conceives migration as a process driven by migrants agency and structured by migration regulations and migration systems, which cluster migration geographically and socially by 'encouraging migration along certain pathways and discouraging it along others' (de Haas 2008, 2I). In this understanding, migration is seen as a complex interaction of human agency and structural constraints and opportunities (Kothari 2002, IO), whereby migrant households and individuals make use of social capital, networks and opportunity structures to improve their living conditions and perspectives (Collinson 2003, 5). Not only migration decisions, but also decisions regarding settlement and naturalisation can

2 The requirement to renounce the nationality of the country of origin raises the costs for naturalisation in particular for persons and households living in a transnational context. In the present paper we control for these regulations by only looking at one destination country, Austria, and by controlling for the countries of origin of the major groups of immigrants in Austria. be understood as an element of migrants' livelihoodstrategies.

Whereas material costs can be measured more easily (fees for naturalisation, costs for documents, or fees for denaturalisation in country of origin if dual nationality is not permitted), personal costs are more complicated to capture theoretically and empirically. Theoretically, we suggest to consider the reasoning on 'identity economics' developed by George Akerlof and Rachel Kranton (2000; 20IO), who argue, that the concept of the self shapes the subjective definition of utility. For persons defining their identity strongly in terms of belonging to a certain national origin, personal costs might diminish or outweigh the likely gains from naturalisation. As Logan et al (2OI2, 550 ) have shown based on an analysis of microdata from the US 2000 census, there is a strong effect of place of residence on naturalisation behaviour - in areas where a higher share of group members already has naturalised, persons were also more likely to take up US nationality, as naturalisation is accepted among the community and thus personal costs reduced. This empirical link supports the theoretical considerations developed above, but there are no empirical studies examining the influence of the self-concept on naturalisation decisions available, and also this paper will leave this aspect aside due to unavailability of information in our data set.

Studies analysing determinants of citizenship acquisition by immigrants emerged in Northern America and Europe only in the past ten years or so with some exceptions. One of the first comprehensive analyses of immigrants' naturalisation practices was published by Philip Yang in 1994, where he analysed the likelihood of naturalisation of the 1970 to 1974 immigrant cohort in the USA. Further research on immigrant naturalisation was mostly published by economists during the last decade or so, asking about the economic impact of naturalisation (e.g. Bratsberg et al. 2002; Kogan 2003; Bevelander/ DeVoretz 2008; Steinhardt 2008; OECD 20II; Corluy et al. 20II). Based on extant literature on citizenship we derive the following hypothesis for the present analysis.

Our first set of hypotheses claims that legal regulations drive the decisions and opportunities to naturalise and the question of whether or not persons remain foreign citizens depends on the costs and benefits of overcoming those regulations. We test this hypothesis by analysing regional differences. In Austria the governments of the Bundesländer are the administrative units executing naturalisation and administrations still have some leeway in decision making (leeway was considerably restricted in 2006). In particular Vienna is known for its more liberal citizenship policy, using its leeway to implement naturalisation laws for promoting naturalisation and requesting lower fees for naturalisation (Hra). Thus we hypothesise that immigrants residing in the city of Vienna, show lower likelihood to be a foreign citizen. 
The next assumption focuses on the 'benefit aspect' of naturalisation. It has been shown, that non-EU citizens show a higher likelihood of seeking citizenship in EU countries, because they gain more rights compared to EU citizens, who already enjoy several rights in other EU countries (H Ib). This has been shown for European countries by simply analysing naturalisation rates (Reichel 20IIa) and is also influenced by the economic situation in the country of origin (e.g. Dronkers/Vink 20I2; Vink et al. 2013). This is also related to the fact that non-EU citizens expect more practical advantage of naturalisation, while EU citizens seek national citizenship in another EU country more because of emotional reasons and attachments (Reichel 20Irb). These emotional reasons are not so easy to measure, except for directly asking questions to naturalisation candidates through surveys among immigrants. Availability of studies going beyond the analysis of economic factors as determining naturalisation propensities but also attitudinal factors and subjective assessments towards citizenship has increased in recent years (Diehl/Blohm 2003; Constant et al. 2007; Ersanili/ Koopmans 20IO; Huddleston/Tjaden 20I2; Hochman 20II; Kahanec/Tosun 2009; Ivlevs/King 2012).

Thirdly we assume that legal restrictions are more easily overcome for persons with higher socio-economic status, because economic resource requirements in citizenship laws are more easily met. We measure socio-economic status through level of education and level of income for employed immigrants (excluding not employed and self employed persons in one model). We assume a negative influence of higher education because higher educated people are expected to have more knowledge about access to citizenship and will find it easier to fulfil requirements such as language skills and income requirements and to pay the fees (HIc). Furthermore, we assume that persons working as white collar workers are less likely to be foreigners compared to blue collar workers and persons who are not employed.

The second strand of hypotheses stems from previous research and theoretical assumptions that show the major influence of the decision to settle in a country as a main driving factor for naturalisation (Reichel 20II; Huddleston/Tjaden 2012). Immigrants who perceive their residence in the destination country as temporary do accept worse conditions (e.g. housing conditions, jobs with lower occupational status) in the destination countries (Piore 1979) and consequently also do not invest so much in their lives in the countries of residence.

Therefore we assume that settlement negatively influences the likelihood of keeping foreign citizenship in Austria (H 2). One indicator for settlement is the length of residence, while immigrants with longer residence show lower likelihood of being a foreign citizen (shown by Dronkers/Vink 20I2; Corluy et al. 2OII) (H2a). In line with models provided by other scholars, we do not ex- pect years of residence to have a linear relationship with citizenship status. Contrary to what other researchers have done so far, we do not only add a squared predictor for years of residence (e.g. Corluy et al. 20II; Hayfron 2008) but also introduce cubed years of residence, which allows the influence of the variable to change its direction more than once.

In addition, we see home ownership as an indicator of settlement in the country, thus assuming that immigrants who do not own their dwelling or house show higher likelihood of remaining foreign citizens (e.g. Yang 1994; Hayfron 2008; DeVoretz/ Pivnenko 2008; Kohlbacher/Reeger 2008) (H2b). Though homeownership has to be understood as an indicator of higher socio-economic status, we think that it is also a strong indicator of settlement, because only persons settling for good would invest in housing in the destination country. For instance in it was shown for Spain that a strong relationship between legal status and homeownership exists beyond socio-economic status (Amuedo-Dorantes/ Mundra 2013) and that homeownership may act as a last trigger to naturalise (Kohlbacher/Reeger 2008). Thirdly, we assume the family situation affects decisions to settle in a country $(\mathrm{H} 2 \mathrm{c})$, also indicated by the importance of extension of naturalisation to children and parents' wish to naturalise for their children (Reichel 20Irb; Street 20I2; Street 2014). We assume that having children as well as being married negatively affect the decision to remain a foreign citizen $(\mathrm{H} 2 \mathrm{c})$.

Closely related to the decision to settle in a country is the actual reason for migration, since mostly refugees as well as family migrants are assumed to be more determined to settle in the destination country and consequently more often opt for citizenship. In fact it was found that refugees, family migrants and persons who immigrated as children are more likely to naturalise in Austria (Reichel 20Irb, I52). For Belgium higher likelihood of naturalisation was found for 'non-Western' immigrants, who came as refugees or for educational purposes as well as higher proportions of naturalised among family migrants from 'Western' countries (Corluy et al. 20II). Other studies show a higher likelihood to naturalise for refugees (e.g. Bevelander/DeVoretz 2008).

We do not have indicators on the reason for migration, but assume that women are less often foreign citizens (Constant et al. 2007) because women more often migrate for the purpose of family reunification (H2d). Studies that control for reasons for migration or other country of origin effects often see the influence of gender disappearing (Yang 1994; Reichel 20Irb; Vink/ Dronkers 2012).

A few studies point to the relationship of naturalisation and emigration, as for instance Ivlevs/King (2012) find that (former) non-citizens in Latvia, who plan to migrate are more likely to have obtained Latvian citizen- 
ship. Bratsberg and Raaum (2OII) show that outmigration of immigrants in Norway is more prevalent among immigrants who do not naturalise. Among immigrants who naturalise the likelihood of emigration is much higher after naturalisation compared to outmigration rates prior to naturalisation. We argue in this case that the underlying factor influencing the naturalisation decision is an immigrant's decision on settlement or emigration/return. Naturalisation in a Western European country has the advantage that it allows to easily return again at a later time and eases the opportunities to travel considerably as compared to passports from a non-EU (or non-EFTA) member state. Having not decided on settlement or thinking about return without coming back to the country lowers the value of host country citizenship and thus persons would not opt for naturalisation.

\section{Data and descriptive statistics}

We use data from the Austrian Mikrozensus 20II. The Mikrozensus is the largest sample survey in Austria covering the total population with large enough samples of immigrants. We restrict our sample to all foreign born persons, who are aged 18 or older and who were born in the main Austrian immigration countries including Turkey, Bosnia and Herzegovina, Serbia, Germany, Croatia and selected regions of origin including Asia, Africa, Bulgaria and Romania, EU-I5 (except Austria and Germany), as well as the three countries of origin Kosovo3, the former Yugoslav Republic of Macedonia and Montenegro lumped together (henceforth KKM). These group compositions were provided as such by Statistics Austria in the micro data. Other groups were excluded due to too low sample sizes. The dataset hence includes only immigrants, but not foreign citizens who were born in Austria. This group was excluded, since it would not allow to include certain variables (e.g. length of residence) and would add more complexity to an already quite complex model. Moreover, the dataset includes persons, who were born abroad as Austrian nationals and moved to Austria at a later stage. This group is considered to be very small and consequently not influencing the outcomes of the analysis.

The total sample size amounts to 7,I42. Of those 58.7 percent are foreign citizens and thus have not naturalised in Austria. Slightly more than half of the sampled immigrants are female of whom 56.7 percent are foreign citizens. Therefore there is a lower share foreign citizens among immigrant women compared to immigrant men. Looking at the four largest immigrant groups in Austria, there are more foreigners among immigrants from Ger-

3 With regard to Kosovo reference is made to the UN Security Council Resolution I244. many (62\%), Bosnia and Herzegovina (65\%) and Serbia (65\%). There are only 52 percent foreigners among immigrants born in Turkey.

While there is no clear difference in the share of foreigners among married immigrants compared to single, divorced or widowed immigrants, among those living in a household with at least one person aged below 15 , the percentage of foreigners is slightly above average at 6I.4 percent.

Looking at groups by level of education there are slightly less foreigners among immigrants with medium education (i.e. vocational training or secondary school without graduation) and clearly more foreigners among immigrants with post secondary education (see Table I). The percentage of foreign citizens among civil servants is at 32.8 percent and therefore much lower compared to the average. The highest percentage of foreigners across different employment statuses is reported for blue collar workers at 62.8 percent.

As indicated above, we expect the length of residence in the country as a major factor negatively influencing the likelihood of not having Austrian citizenship. The average years of residence is 22.I, ranging from one year up to 9I years. The average number of years of residence is much lower among foreign citizens at 15.3 years (median I3 years) compared to those immigrants who hold Austrian citizenship at 31.8 years (median 25 years). The diminishing percentage of foreign citizens among immigrants by length of residence is shown in Figure I.

Immigrants from former 'guestworker' sending countries show on average a longer length of residence. Mean length of residence of immigrants from Africa, Asia, Bulgaria and Romania are clearly below average constituting groups of more recent immigration. Among immigrants from EU-I5 countries and Germany, there is a fair share with longer years of residence (third quartile at 47 and 40 years) and a considerable share of immigrants with shorter duration of residence (first quartile at eight and six years respectively).

The analysis controls for NUTS2 region in Austria, which is important due to different policy approaches in the Bundesländer, but also because the Mikrozensus uses a stratified sampling strategy with the nine Austrian Bundesländer as strata.

Finally, the Mikrozensus 20II provides monthly net income through wages of all employees (thus excluding self-employed, unemployed and inactive persons). The median monthly net income in the sample is I,516 Euros. Lowest median income is found for immigrants from Asia at I,283 Euros followed by immigrants from KKM and Africa at I,352 and I,366 Euros respectively. The highest median income is observed for immigrants from EU-I5 countries and Germany at I,84O and I,756 Euros. There is no statistically significant difference in the mean wages of foreign citizens compared 
Table 1: Descriptive Statistics

\begin{tabular}{|c|c|c|c|}
\hline Variable & $\%$ of total sample & $\%$ foreign citizens & Number of observations \\
\hline Total & $100 \%$ & $58.7 \%$ & 7142 \\
\hline Female (0=men, $1=$ women) & $52.8 \%$ & $56.7 \%$ & 3768 \\
\hline \multicolumn{4}{|l|}{ Country of birth } \\
\hline Turkey & $18.54 \%$ & $52.1 \%$ & 1324 \\
\hline Africa & $2.65 \%$ & $46.6 \%$ & 189 \\
\hline Asia & $7.84 \%$ & $53.2 \%$ & 560 \\
\hline Bosnia and Herzegovina & $16.40 \%$ & $64.8 \%$ & 1171 \\
\hline Bulgaria and Romania & $6.23 \%$ & $52.6 \%$ & 445 \\
\hline Germany & $21.59 \%$ & $63.6 \%$ & 1542 \\
\hline EU 15 countries* & $7.52 \%$ & $61.6 \%$ & 537 \\
\hline Kosovo, Macedonia, Montenegro (KMM) & $4.80 \%$ & $55.1 \%$ & 343 \\
\hline Croatia & $4.16 \%$ & $48.8 \%$ & 297 \\
\hline Serbia & $10.28 \%$ & $65.0 \%$ & 734 \\
\hline Married (married $=1$, else $=0$ ) & $67.08 \%$ & $58.4 \%$ & 4791 \\
\hline Children below 15 ( $1=$ yes, $0=$ no) & $35.73 \%$ & $61.4 \%$ & 2552 \\
\hline \multicolumn{4}{|l|}{ Education } \\
\hline High (tertiary education, ISCED 5, 6) & $12.70 \%$ & $65.6 \%$ & 907 \\
\hline Higher (secondary education, ISCED 3, 4) & $13.89 \%$ & $59.4 \%$ & 992 \\
\hline $\begin{array}{l}\text { Middle (vocational training and secondary schools without } \\
\text { graduation, ISCED } 3,4 \text { ) }\end{array}$ & $36.10 \%$ & $55.4 \%$ & 2578 \\
\hline Low (primary school or less, ISCED 1, 2) & $37.31 \%$ & $59.3 \%$ & 2665 \\
\hline \multicolumn{4}{|l|}{ Employment status } \\
\hline White collar (Angestellte) & $20.54 \%$ & $60.1 \%$ & 1467 \\
\hline Blue collar (Arbeiter) & $29.75 \%$ & $62.8 \%$ & 2125 \\
\hline Civil servants and public administration & $1.67 \%$ & $32.8 \%$ & 119 \\
\hline Self employed & $5.29 \%$ & $55.3 \%$ & 378 \\
\hline Unemployed & $4.90 \%$ & $58.3 \%$ & 350 \\
\hline Inactive & $36.91 \%$ & $56.0 \%$ & 2636 \\
\hline Other & $0.94 \%$ & $68.7 \%$ & 67 \\
\hline \multicolumn{4}{|l|}{ Housing } \\
\hline Tenancy & $60.29 \%$ & $64.3 \%$ & 4306 \\
\hline House owner or relative of house owner & $23.45 \%$ & $45.1 \%$ & 1675 \\
\hline Other & $5.32 \%$ & $72.1 \%$ & 380 \\
\hline Apartment owner & $10.94 \%$ & $50.3 \%$ & 781 \\
\hline
\end{tabular}

Data: Mikrozensus 2011, Statistics Austria

* We tested many variants of modelling age and years of residence using different categories of values and transformations. The present model shows the best results in terms of error distributions and predictive power of the model. 
Figure 1: Percent of immigrants naturalised aged 18 or above by length of residence

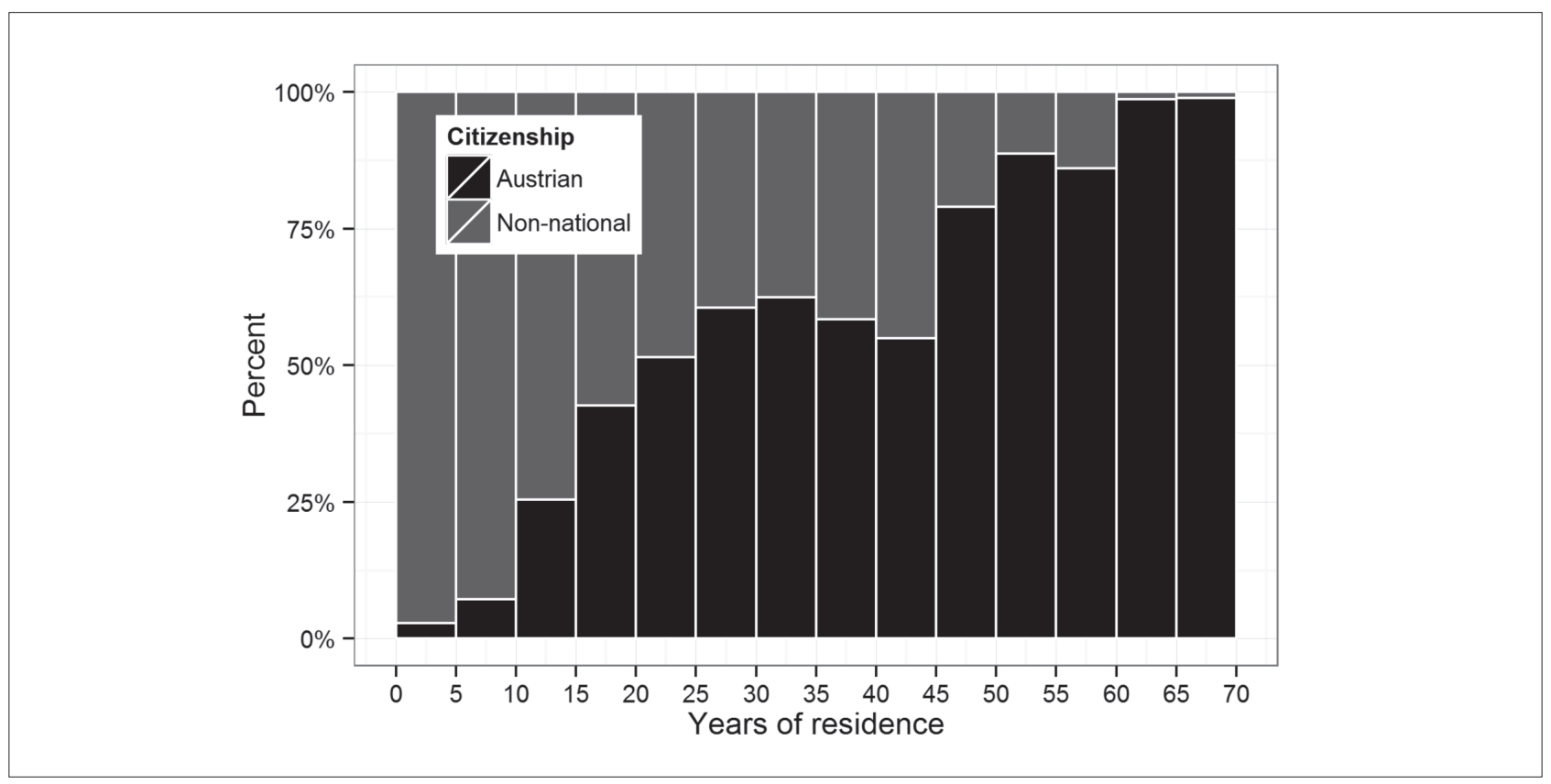

Data: Mikrozensus 2011, Statistics Austria

Figure 2: Employee income of immigrants by country of birth and citizenship status persons aged 25 to 54 with residence $>10$ years

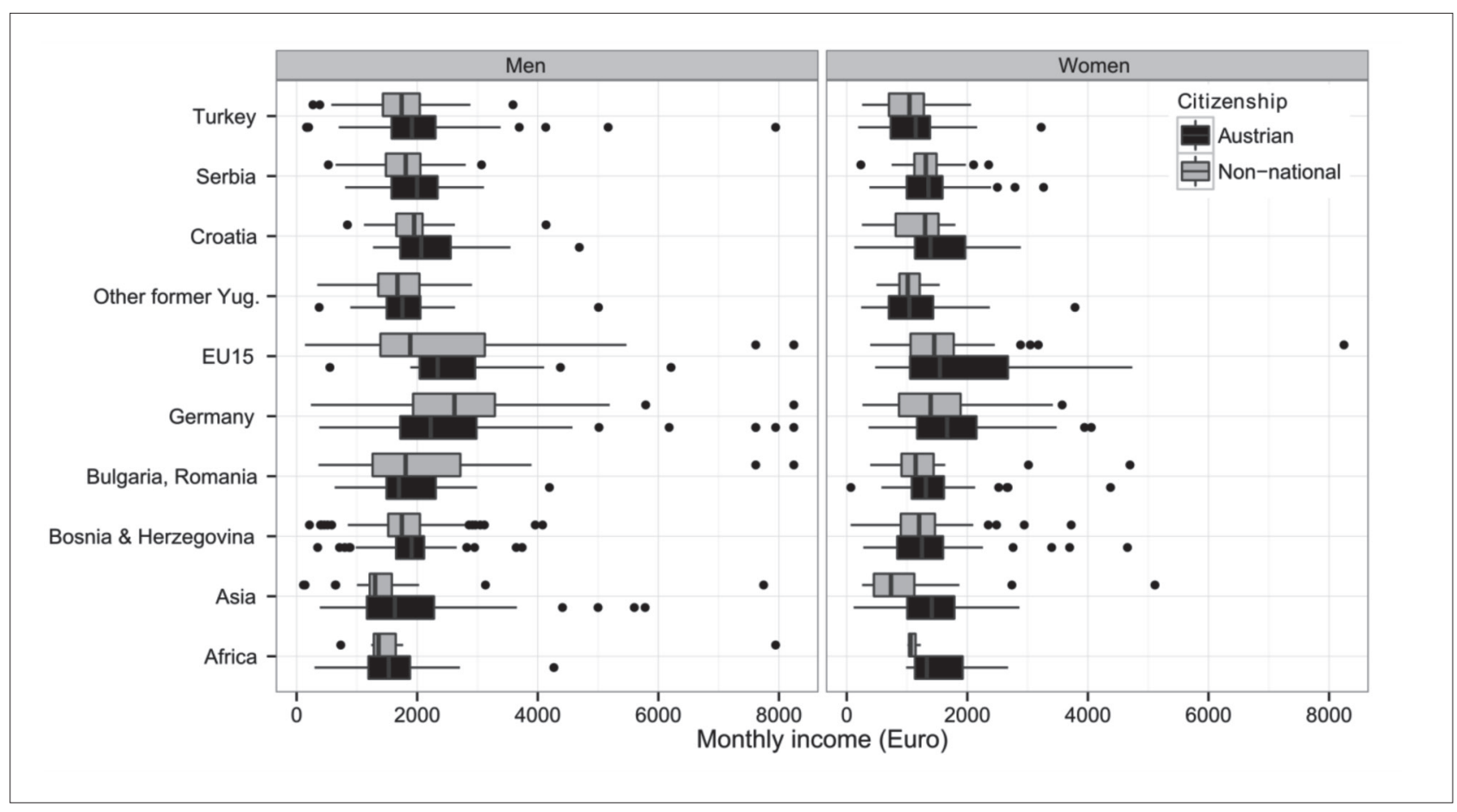

Data: Mikrozensus 2011, Statistics Austria, N = 3142 
to Austrian citizens in the sample, neither for women nor for men. Looking at differences within country of origin groups by gender there is a tendency observable that Austrian citizens earn more. Among immigrants from Turkey there is a significant difference in income at the 0.05 level for men and for women. German immigrants do not show significant differences for men or for women. Mean incomes differ by citizenship status among Serbian male immigrants but not for females and for Croatia it is the other way round. Figure 2 graphically shows the distributions of monthly net income for immigrants residing in Austria for more than ten years. The relationship of income and citizenship status will be further explored in the logistic regression models below. Although we argue that our independent variables influence the outcome of citizenship status, we recognise that citizenship acquisition might also have an effect on certain socio-demographic variables after naturalisation.

\section{Results - modelling citizenship status}

In our first regression we look at citizenship status of all immigrant groups lumped together by years of residence, age at migration and Bundesland (see Model o in Table $2 \mathrm{a} / \mathrm{b}$ ). We find significant negative influence of years of residence on having foreign citizenship. Years of residence in the country squared yields a positive influence and years of residence cubed again a negative influence. Figure 3 graphs this relationship for the reference Bundesland (city of Vienna). It clearly shows that there is a strong decrease in the likelihood of being a foreign citizen in the first 22 to 23 years of residence and this decrease slows considerably down in the years thereafter. Only after some 43 years of residence the likelihood of being a foreign citizen decreases again at a faster pace and slows down again after 63 years of residence. This pattern points to the difficulties of immigrants who arrived between the end of the I960s and I980s, who were mostly workers for low-skilled and low-paid jobs (socalled 'guestworkers' and their relatives). Persons who immigrated as children show a lower likelihood of being foreign citizens, which means that the older persons at the time of immigration, the lower the likelihood of having naturalised. This relationship is not only a function of time but also of age. ${ }^{4}$

Required length of residence is one of the most obvious restrictions for applying for citizenship. Since all immigrants are allowed to apply for citizenship after ten years of residence, we restrict the sample in our models to all immigrants residing in Austria for more

4 We tested many variants of modelling age and years of residence using different categories of values and transformations. The present model shows the best results in terms of error distributions and predictive power of the model. than ten years. ${ }^{5}$ Tables $2 a$ and $2 b$ show the results of our logistic regression models. In Model 2 we test the general differences between countries of origin (Model I is the same but without the restriction by length of residence). Model 3 adds our predictors for socio-economic status and settlement. The last model (Model 4) restricts the analysis to all employed immigrants, which allows us including monthly net income to the model. We also add household size to the regressions because the survey samples households and not individuals.

Figure 3: Influence of years of residence on the likelihood of being foreign citizen for different groups of age at migration (predicted values from logistic regression)

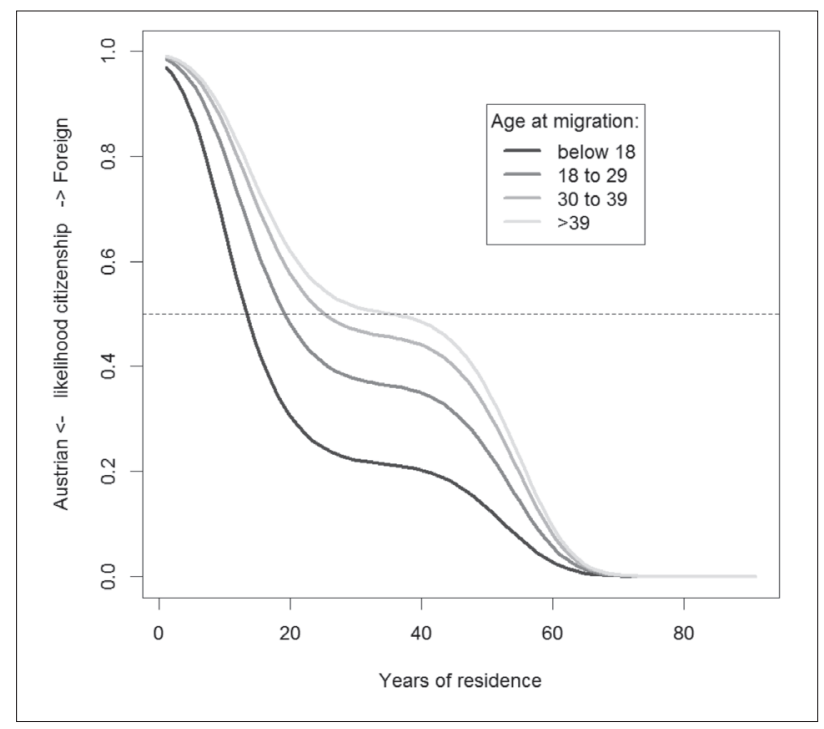

All models confirm the changing importance of years of residence for citizenship acquisition, taking a similar shape as shown in Figure 3 (confirmation of H2a). We can also confirm a higher likelihood of being a foreigner for immigrants, who were older at the time of migration in the first two models. We only find limited evidence on this relationship when looking at employed immigrants only and including income to the model, but this might also be related to lower numbers of observations in Model 4 .

We do find some support for our first hypothesis that immigrants are less likely to be foreigners in Vienna (Hra). Most notably immigrants are more likely to be foreigners in Carinthia, Salzburg and Vorarlberg as compared to the city of Vienna and less likely to be foreigners in Burgenland. This fact might be explained by a rather restrictive position of the provincial governments towards immigration - as compared to Vienna - on the one hand, but also by the fact, that these Bundesländer are strong in tourism and thus have a high share of sea-

5 Most immigrants who naturalise in Austria do so after I2 to 15 years of residence (Reichel 2OIIb; Reichel 2012). 
Table 2 a: Results of logistic regressions estimating the likelihood of being a foreign citizen for immigrants aged 18 and older with over ten years of residence in Austria (continues in Table $2 b$ )

\begin{tabular}{|c|c|c|c|c|c|}
\hline & $\begin{array}{l}\text { Model } 0 \\
\text { All immigrants }\end{array}$ & $\begin{array}{l}\text { Model } 1 \\
\text { All immigrants }\end{array}$ & $\begin{array}{l}\text { Model } 2 \\
\text { Residence } \\
>10 \text { years }\end{array}$ & $\begin{array}{l}\text { Model } 3 \\
\text { Residence } \\
>10 \text { years }\end{array}$ & $\begin{array}{l}\text { Model } 4 \\
\text { Residence } \\
>10 \text { years }\end{array}$ \\
\hline Variable & Coefficient (s.e.) & Coefficient (s.e.) & Coefficient (s.e.) & Coefficient (s.e.) & Coefficient (s.e.) \\
\hline YSM & $-0.437(0.211)^{\star \star \star}$ & $-0.483(0.026)^{\star \star \star}$ & $-0.379(0.049)^{\star \star \star}$ & $-0.324(0.050)^{\star \star *}$ & $-0.342(0.093)^{\star \star *}$ \\
\hline YSM Squared & $0.013(0.000)^{\star \star *}$ & $0.013(0.001)^{\star \star *}$ & $0.010(0.002)^{\star * \star}$ & $0.008(0.002)^{\star \star *}$ & $0.008(0.003)^{*}$ \\
\hline YSM Cube & $-1 e-4(0.000)^{\star \star \star *}$ & $-1 e-4(0.000)^{* * *}$ & $-1 e-4(0.000)^{\star \star \star}$ & $0.000(0.000)^{\star \star \star}$ & $0.000(0.000)^{*}$ \\
\hline A@M $<18$ & Ref & Ref & Ref & Ref & Ref \\
\hline A@M 18-29 & $0.746(0.069)^{\star \star \star *}$ & $0.780(0.071)^{\star * *}$ & $0.711(0.075)^{\star * *}$ & $0.397(0.116)^{\star \star \star}$ & $0.122(0.156)$ \\
\hline A@M 30-39 & $1.130(0.091)^{\star * *}$ & $1.176(0.095)^{* * *}$ & $1.192(0.101)^{\star * *}$ & $0.601(0.146)^{\star * *}$ & $0.426(0.206)^{*}$ \\
\hline A@M 40+ & $1.308(0.129)^{\star * *}$ & $1.197(0.135)^{\star * *}$ & $1.310(0.152)^{\star \star *}$ & $0.422(0.199)^{*}$ & $-0.236(0.389)$ \\
\hline Vienna & Ref & Ref & Ref & Ref & Ref \\
\hline Burgenland & $-0.820(0.171)^{\star * *}$ & $-0.676(0.180)^{\star \star *}$ & $-0.580(0.202)^{\star \star}$ & $-0.327(0.212)$ & $-0.689(0.313)^{*}$ \\
\hline Carinthia & $0.563(0.128)^{\star \star \star *}$ & $0.407(0.137)^{\star \star}$ & $0.515(0.145)^{\star \star * *}$ & $0.688(0.153)^{\star * *}$ & $0.566(0.212)^{* *}$ \\
\hline Lower Austria & $0.262(0.111)^{*}$ & $0.279(0.117)^{\star}$ & $0.312(0.124)^{*}$ & $0.525(0.132)^{\star * *}$ & $0.267(0.188)$ \\
\hline Upper Austria & $0.077(0.105)$ & $-0.039(0.112)$ & $0.104(0.121)$ & $0.148(0.127)$ & $0.033(0.173)$ \\
\hline Salzburg & $0.638(0.102)^{\star \star *}$ & $0.524(0.108)^{\star \star \star \star}$ & $0.575(0.114)^{\star \star *}$ & $0.696(0.120)^{\star \star \star *}$ & $0.674(0.106)^{\star * *}$ \\
\hline Styria & $0.125(0.136)$ & $0.131(0.145)$ & $0.248(0.157)$ & $0.366(0.164)^{*}$ & $0.092(0.226)$ \\
\hline Tyrol & $0.383(0.104)^{\star * *}$ & 0.218 (0.112) & $0.288(0.119)^{*}$ & $0.352(0.125)^{\star *}$ & $0.156(0.179)$ \\
\hline Vorarlberg & $0.554(0.097)^{\star \star \star}$ & $0.553(0.104)^{\star * *}$ & $0.646(0.110)^{\star * *}$ & $0.797(0.116)^{\star \star \star}$ & $0.692(0.162)^{\star \star \star}$ \\
\hline Turkey (Ref.) & - & Ref & Ref & Ref & Ref \\
\hline Africa & - & $-1.302(0.206)^{\star \star \star}$ & $-1.568(0.280)^{\star \star *}$ & $-1.240(0.293)^{\star \star *}$ & $-0.922(0.396)^{\star}$ \\
\hline Asia & - & $-0.816(0.132)^{\star \star *}$ & $-0.955(0.153)^{* * *}$ & $0.476(0.164)^{\star *}$ & $-0.345(0.230)$ \\
\hline Bosnia \& Herz. & - & $0.591(0.097)^{\star \star *}$ & $-0.589(0.100)^{\star \star *}$ & $0.924(0.110)^{\star * *}$ & $0.992(0.150)^{\star \star \star}$ \\
\hline Bulg. \& Rom. & - & $-0.700(0.155)^{\star \star \star}$ & $-1.130(0.192)^{\star * *}$ & $-0.604(0.202)^{\star *}$ & $-0.301(0.268)$ \\
\hline Germany & - & $0.484(0.108)^{\star \star \star}$ & $0.471(0.113)^{\star \star *}$ & $1.504(0.149)^{\star \star \star}$ & $2.110(0.219)^{\star \star \star}$ \\
\hline EU-15 & - & $0.864(0.156)^{\star * \star}$ & $0.912(0.161)^{\star \star * *}$ & $1.924(0.192)^{\star \star \star \star}$ & $2.523(0.295)^{\star \star \star}$ \\
\hline KMM & - & $-0.472(0.150)^{\star *}$ & $-0.577(0.166)^{* * *}$ & $-0.389(0.173)^{\star}$ & $-0.467(0.249)$ \\
\hline Croatia & - & $0.352(0.153)^{*}$ & $0.331(0.157)^{\star}$ & $0.805(0.168)^{\star \star \star}$ & $1.239(0.236)^{\star \star \star}$ \\
\hline Serbia & - & $1.202(0.116)^{\star \star *}$ & $1.226(0.119)^{\star \star \star}$ & $1.443(0.127)^{\star * *}$ & $1.479(0.179)^{\star \star \star}$ \\
\hline
\end{tabular}


Table 2 b: Results of logistic regressions estimating the likelihood of not having naturalised of immigrants aged 18 and older with over ten years of residence in Austria (continued)

\begin{tabular}{|c|c|c|c|c|c|}
\hline & $\begin{array}{l}\text { Model } 0 \\
\text { All immigrants }\end{array}$ & $\begin{array}{l}\text { Model } 1 \\
\text { All immigrants }\end{array}$ & $\begin{array}{l}\text { Model } 2 \\
\text { Residence } \\
>10 \text { years }\end{array}$ & $\begin{array}{l}\text { Model } 3 \\
\text { Residence } \\
>10 \text { years }\end{array}$ & $\begin{array}{l}\text { Model } 4 \\
\text { Residence } \\
>10 \text { years }\end{array}$ \\
\hline Variable & Coefficient (s.e.) & Coefficient (s.e.) & Coefficient (s.e.) & Coefficient (s.e.) & Coefficient (s.e.) \\
\hline Education Low & - & - & - & Ref & Ref \\
\hline Education Mid & - & - & - & $-0.455(0.087)^{\star \star \star}$ & $-0.363(0.120)^{\star *}$ \\
\hline Educ. Higher & - & - & - & $-0.693(0.123)^{\star \star * *}$ & $-0.683(0.167)^{\star \star \star \star}$ \\
\hline Education High & - & - & - & $-0.379(0.147)^{\star *}$ & $-0.314(0.213)$ \\
\hline $\begin{array}{l}\text { Education after } \\
\text { immigration }\end{array}$ & - & - & - & $-0.337(0.121)^{\star \star}$ & $-0.343^{*}$ \\
\hline Married & - & - & - & $-0.049(0.085)$ & $-0.273(0.124)^{*}$ \\
\hline Children below 15 & - & - & - & $-0.237(0.085)^{\star \star}$ & $-0.302(0.108)^{\star *}$ \\
\hline Empl: White Collar & - & - & - & Ref & Ref \\
\hline Empl: Other & - & - & - & $0.404(0.379)$ & - \\
\hline Empl: Blue Collar & - & - & - & $0.135(0.104)$ & $0.329(0.118)^{\star \star}$ \\
\hline Empl: Unemployed & - & - & - & $0.063(0.169)$ & - \\
\hline $\begin{array}{l}\text { Empl: } \\
\text { Civil Service }\end{array}$ & - & - & - & $-0.876(0.298)^{\star \star}$ & $-0.973(0.310)^{\star *}$ \\
\hline Empl: Inactive & - & - & - & $0.578(0.111)^{\star \star \star *}$ & - \\
\hline $\begin{array}{l}\text { Empl: Self- } \\
\text { employed }\end{array}$ & - & - & - & $-0.017(0.169)$ & - \\
\hline Tenancy & - & - & - & Ref & Ref \\
\hline $\begin{array}{l}\text { House owner or } \\
\text { relative }\end{array}$ & - & - & - & $-0.759(0.095)^{\star \star *}$ & $-0.743(0.134)^{\star * *}$ \\
\hline Other & - & - & - & $0.411(0.166)^{*}$ & $0.437(0.228)$ \\
\hline Owner appartment & - & - & - & $-0.372(0.108)^{\star \star \star \star}$ & $-0.285(0.146)$ \\
\hline Female & - & - & - & $-0.512(0.071)^{\star * *}$ & $-0.581(0.107)^{\star \star *}$ \\
\hline $\begin{array}{l}\text { Household Size } \\
\left(18^{+}\right)\end{array}$ & - & - & - & $-0.075(0.041)$ & $0.063(0.055)$ \\
\hline $\begin{array}{l}\text { Log. of monthly } \\
\text { income }\end{array}$ & - & - & - & - & $-0.217(0.091)^{*}$ \\
\hline Intercept & $3.890(0.211)^{\star \star \star}$ & $4.324(0.239)^{\star \star *}$ & $3.218(0.490)^{\star \star *}$ & $3.393(0.552)^{\star * *}$ & $5.939(1.11)^{\star \star \star}$ \\
\hline $\mathrm{N}$ & 7142 & 7142 & 7142 & 7142 & 3633 \\
\hline AIC & 6981.4 & 6602.5 & 5729.9 & 5486.7 & 2907.2 \\
\hline Nagelkerke Index & 0.43 & 0.48 & 0.33 & 0.38 & 0.33 \\
\hline Cox \& Snell Index & 0.32 & 0.36 & 0.25 & 0.28 & 0.25 \\
\hline
\end{tabular}


sonal employment of immigrants and consequently temporary employment. The models clearly confirm the higher likelihood of immigrants from other EU-I5 countries to retain their citizenship and not to opt for Austrian citizenship (Hrb). Compared to immigrants born in an EU-I5 country all other groups of origin show a lower likelihood of having foreign citizenship. If we look at German immigrants as reference group all groups are less likely to be foreign citizens except for other EU-I5 immigrants and the lower likelihood of being a foreigner of Serbian immigrants compared to Germans is statistically not significant. These results are strong evidence for the lower value of Austrian citizenship for EU migrants.

Looking at the three major groups of immigrants to Austria from 'guestworker' recruitment and subsequent chain immigration, immigrants from former Yugoslavian countries, most notably from Serbia, Bosnia and Herzegovina and Croatia, are significantly more likely to be foreign citizens compared to Turkish immigrants. One of the reasons why immigrants from these countries are less likely to acquire Austrian citizenship might be explained by the fact that giving up citizenship in their countries of origin would lead to the loss of important rights in their countries of origin (e.g. inheritance, etc.). This is not so much of a problem for former Turkish citizens since the introduction of the then called 'pink card' at the end of the I990s (Cinar 2006). The importance of having rights in the country of origin is related to existing plans to return, which means that the decision to settle permanently in the destination country reduces the value of citizenship in the country of origin and hence increases the likelihood to naturalise (in case renunciation of previous citizenship is required). With regard to the lower likelihood of being a foreign citizen for immigrants with higher socio-economic status (HIc), we find that higher education decreases the likelihood of being a foreign citizen in line with our assumptions and previous findings of other studies. Being highly educated (tertiary education) does not show a clear effect, especially when controlling for income. However, we find that having completed education in Austria has a negative influence on being a foreigner. Compared to white collar workers economically inactive persons show a higher likelihood and civil servants show a lower likelihood of having foreign citizenship. The latter is partly related to requirements for citizenship for accessing civil service (as discussed in OECD 2010, 157-186). The higher likelihood of inactive persons points to lack of resources for naturalisation and might especially concern women, though we could not find an interaction effect of employment status and gender on citizenship status. When looking only at employed immigrants and controlling for income, we find that blue collar workers are more likely foreign citizens.
We find a low but statistically significant influence of income on being a foreign citizen. The higher the net income of employed immigrants the lower the likelihood of holding foreign citizenship. Immigrants with lower income are more likely to have kept their citizenship of origin instead of having naturalised in Austria. It is important to note that this effect is only significant for men. Although the direction of the effect is the same for women, it is statistically not significant. Figure 4 shows the estimated influence of (the logarithm) of income on the likelihood of being a foreign citizen for male immigrants with average years of residence in Austria and all other reference categories in Model 4 (immigrated from Turkey to Austria before they turned I8, live in Vienna, low education, not married, no children, single household, white collar workers, etc.). According to our model, the likelihood of being a foreigner in Austria turns below 0.5 at a log of income of 6.97, which equals a monthly net income threshold of I,O7I Euros. This means that persons earning less are unlikely to have naturalised and points to the selective effect of citizenship according to income, whereas richer immigrants do naturalise easier.

Our second set of hypotheses concerns indicators for permanent settlement in Austria. The influence of duration of residence ( $\mathrm{H} 2 \mathrm{a}$ ) can be seen as confirmed (see above). As assumed there is no linear relationship of years of residence on acquisition of citizenship.

We do not find strong support for a negative influence of being married on being a foreigner. However, there is a clear difference between persons living in a household with children aged below I5. The presence of children in the household leads to higher probability of having Austrian citizenship, thus there is a clear intergenerational effect on citizenship acquisition (Street 20I4).

Finally, as an indicator for settlement in Austria, home ownership obviously influences citizenship status. This means that persons who do not own their dwellings or houses are much likelier foreign citizens. We explain this influence by the fact that persons who own their house or dwelling have - besides the availability of resources - decided to stay in the country and therefore also invested more into their lives in Austria.

As a last point, we find strong influence of gender on citizenship status. Men are much more likely to be foreign citizens. As discussed above, this result might be influenced by the fact that women more often migrate for family reasons and therefore assume settlement in the destination country. However, this relationship and the general influence of gender definitely need further research.

Finally, we run Model 4 for the main groups of immigrants separately. Due to low sample sizes and given the size of the model, we do not find much evidence because of large standard errors. However, we can report a few interesting findings from splitting the sample by 
Figure 4: Estimated likelihood of being a foreign citizen by logarithm of monthly net income for male immigrants from Turkey at mean length of residence (and other baseline variables in Model 4 above)

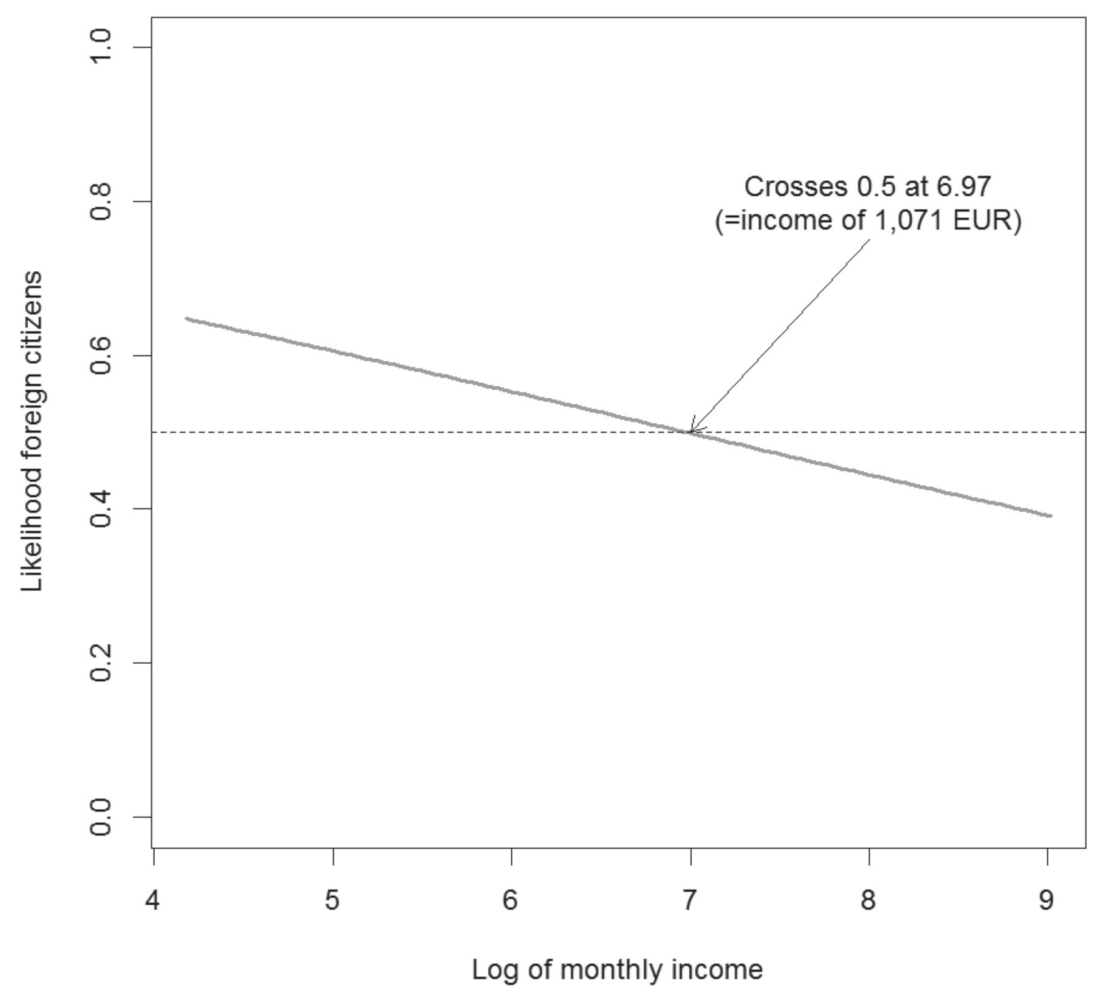

country of origin. We can confirm the importance of being a house owner for all groups except for Germans and owning a dwelling is only confirmed for Turkish immigrants with our sample. A higher naturalisation propensity for women is shown for all groups, though we cannot confirm this with certainty for Germans. The importance of education can only be confirmed for Bosnian immigrants. Being a civil servant shows an effect for Germans only and an influence of being a blue collar worker compared to white collar is only positive for Bosnians, Serbs and Turks (but not statistically significant for the latter group). Finally, we find strong influence of age at migration for German immigrants, which cannot be found for the other groups.

\section{Conclusions}

A person's decision to naturalise is driven by a variety of factors and can be viewed as a cost-benefit model characterised by legal constraints and a trade-off between the (potential) loss and gain of rights, as defined by the policies of origin and destination countries. The more persons are settled in a country the higher the subjective value of host country citizenship, which leads to the acceptance of higher costs for citizenship acquisition. We find that lower socio-economic status and lower income are the most important economic predictors for nonnaturalisation. This result points to a socio-economic selection process set in pace by the naturalisation regulations. If these criteria cannot be fulfilled, persons refrain from acquiring citizenship, as they either cannot or do not want to pay the costs of naturalisation.

Holding the passport of an EU member state is a strong predictor for non-naturalisation. In this case, the low added value of acquiring Austrian citizenship is the main reason against Austrian citizenship. Finally, home ownership clearly points to the importance of the decision of long-term settlement and thus highlights the need to understand naturalisation also from the perspective of migrant agency.

We can argue that people want to naturalise either because they see the need for improvement (e.g. on the labour market and access to rights, etc.) or they already feel integrated and want to adjust their legal status to their already felt integration. Since settlement also raises the emotional attachment to the host country, it increases the value of host country citizenship. Yet there is a lack of research on how subjective and emotional aspects are influenced by and how they interact with legal-structural definitions of citizenship or potential discrimination experiences. 
We would like to close this study with two normative questions arising from the results of our research, where we change the focus from the individual to the nation state. It is clear that legal regulations design characteristics of new citizens, which are particularly persons with higher socio-economic status. The first question is whether it is desirable for democratic societies to exclude persons from certain rights, most notably suffrage, because they do not fare well on the labour market or simply do not earn much. The second question to be raised is whether or not democratic nation states should do more to incorporate immigrants in order to maintain their democratic legitimacy. Is it not questionable if access to political participation in the sense of voting is left to national citizenship, which is driven by a complex sociological and political selection process, designed by policies in the destination countries, countries of origin and migrants' agency?

\section{References}

Akerlof, George A./Rachel E. Kranton (2000). Economics and Identity, in: The Quarterly Journal of Economics, Vol. CXC(3), 715-753.

Akerlof, George A./Rachel E. Kranton (2010). Identity Economics: How Our Identities Shape Our Work, Wages, and Well-Being, Princeton.

Amuedo-Dorantes, Catalina/Kusum Mundra (20I3). Immigrant Homeownership and Immigration Status: Evidence from Spain, CReAM Discussion Paper Series, CDP No oI/13, London.

Bauböck, Rainer (2007). Stakeholder Citizenship and Transnational Political Participation: A Normative Evaluation of External Voting, in: Fordham Law Review, Vol. 75 (5), 2393-2447.

Bauböck, Rainer (2OI2). Constellations and Transitions: Combining Macro and Micro Perspectives on Migration and Citizenship, in: Michi Messer/Renée Schroeder/Ruth Wodak (ed.): Migrations: Interdisciplinary Perspectives, Vienna et al, 3-I4.

Bauböck, Rainer/Eva Ersboll/Kees Groenendijk/Harald Waldrauch (eds.) (2006). Acquisition and Loss of Nationality. Policies and Trends in I5 European States. Volume I: Comparative Analyses, Amsterdam.

Bevelander, Pieter/Don DeVoretz (eds.) (2008). The Economics of Citizenship, Malmö.

Bourdieu, Pierre (1993). Sozialer Sinn. Kritik der theoretischen Vernunft, Frankfurt am Main.

Bratsberg Bernt/James F. Ragan/Zafar M. Nasir (2002). The Effect of Naturalisation on Wage Growth: A Panel Study of Young Male Immigrants, in: Journal of Economics, Vol. 2O(3), 568-597.
Bratsberg Bernt/Oddbjorn Raaum (20II). The Labour Market Outcomes of Naturalised Citizens in Norway, in: Naturalisation: A Passport for the Better Integration of Immigrants? OECD Publishing, I84-205.

Cinar, Dilek (2006). The politics of external citizenship the case of Turkey. Text Box 4, in: Rainer Bauböck (ed.) Migration and Citizenship. Legal Status, Rights and Political Participation, Amsterdam.

Cinar, Dilek/Harald Waldrauch (2006). Austria, in: Rainer Bauböck/Eva Ersboll/Kees Groenendijk/Harald Waldrauch (eds.): Acquisition and Loss of Nationality. Policies and Trends in 15 European States. Volume 2: Country Analyses, Amsterdam, 19-62.

Collinson, Sarah (2003). Introduction, in: Sarah Collinson (ed.): Power, livelihood and conflict: case studies in political economy analysis for humanitarian action. HPG Report 13, London.

Constant, Amelie F./Liliya Gataullina/Klaus F. Zimmermann (2007). Naturalisation Proclivities, Ethnicity and Integration. IZA Discussion Paper Series No. 3260.

Corluy, Vincent/Ive Marx/Gerlinde Verbist (2OII). Employment chances and changes of immigrants in Belgium: The impact of citizenship, in: International Journal of Comparative Sociology, Vol. 52, 350-368.

Diehl, Claudia/Michael Blohm (2003). Rights or Identity? Naturalisation Processes among 'Labour Migrants' in Germany, in: International Migration Review, Vol. 37(I), I33-I62.

Dronkers, Jaap/Maarten P. Vink (2012). Explaining Access to Citizenship in Europe: How Policies Affect Naturalisation Rates, in: European Union Politics, Vol. I3(3), 390-4I2.

Ersanilli, Evelyn/Ruud Koopmans (2010). Rewarding Integration? Citizenship Regulations and the Socio-Cultural Integration of Immigrants in the Netherlands, France and Germany, in: Journal of Ethnic and Migration Studies, Vol. 36(5), 773 - 79I.

Goodman, Sarah W. (2010). Naturalisation Policies in Europe: Exploring Patterns of Inclusion and Exclusion, EUDO Citizenship Comparative Reports.

De Haas, Hein (2008). Migration and development. A theoretical perspective, International Migration Institute Working Paper 9, Oxford.

Hayfron, John E. (2008). The Economics of Norwegian Citizenship, in: Pieter Bevelander/Don DeVoretz (eds.): The Economics of Citizenship, Malmö, 89-IO4.

Hochman, Oshrat (20II). Determinants of Positive Naturalisation Intentions among Germany's Labour Migrants, in: Journal of Ethnic and Migration Studies, Vol. 37(9), I403-I42I.

Huddleston, Thomas/Jasper D. Tjaden (2012). Immigrant Citizens Survey. How immigrants experience integration in I5 European cities, Brussels. 
Ivlevs, Artjoms/Roswitha M. King (2012). From immigrants to (non-)citizens: Political economy of naturalisations in Latvia, in: IZA Journal of Migration, Vol. I(I4), I-23.

Kahanec, Martin/Mehmet S. Tosun (2009). Political Economy of Immigration in Germany: Attitudes and Citizenship Aspirations, in: International Migration Review, Vol. 43(2), 263-29I.

Kogan, Irene (2003). Ex-Yugoslavs in the Austrian and Swedish labour markets: the significance of the period of migration and the effect of citizenship acquisition, in: Journal of Ethnic and Migration Studies, Vol. 29(4), 595-622.

Kohlbacher, Josef/Ursula Reeger (2008). Staatsbürgerschaftsbonus beim Wohnen? Eine empirische Analyse der Unterschiede zwischen eingebürgerten und nichteingebürgerten Zuwander/-innen hinsichtlich ihrer Wohnsituation in Wien. ISR Forschungsberichte Heft 35, Wien.

Kothari, Uma (2002). Migration and Chronic Poverty, Working Paper No. 16, University of Manchester, Chronic Poverty Research Centre.

Logan, John R./Oh Sookhee/Jennifer Darrah (2012). The Political and Community Context of Immigrant Naturalisation in the United States, in: Journal of Ethnic and Migration Studies, Vol. 38, 535-554.

Mazzolari, Francesca (2009). Dual Citizenship Rights: Do They Make More and Richer Citizens?, in: Demography, Vol. 46(I), I69-I9I.

OECD (20IO). International Migration Outlook, SOPEMI 2010.

OECD (2OII). Naturalisation: A Passport for the Better Integration of Immigrants?, OECD Publishing.

Piore, Michael J. (1979). Birds of Passage: Migrant Labour and Industrial Societies, Cambridge.

Reichel David (2011a). Do Legal Regulation Hinder Naturalisation? Citizenship Policies and Naturalisation Rates in Europe, EUI Working Papers, RSCAS 20II/5I.

Reichel David (2OIrb). Staatsbürgerschaft und Integration. Die Bedeutung der Einbürgerung für MigrantInnen, Wiesbaden.

Reichel David (2012). Political Incorporation of Immigrants - Naturalisation Rates in Europe, ICMPD Working Paper 04, Vienna.

Steinhardt, Max F. (2008). Does citizenship matter? The economic impact of naturalisations in Germany, HWWI Research paper, Hamburg, 3-I3.

Stern, Joachim/Gerd Valchars (2013). Naturalisation Procedures for Immigrants Austria, EUDO Citizenship Observatory.

Street, Alex (2011). Citizenship Begins at Home: How Families Shape Immigrant Incorporation, PhD dissertation, Berkeley.
Street, Alex (2014). My Child Will Be a Citizen: Intergenerational Motives for Naturalization, in: World Politics, Vol. 66(2), 264-292.

Vink, Maarten P./René de Groot (20I0). Citizenship Attribution in Western Europe: International Framework and Domestic Trends, in: Journal of Ethnic and Migration Studies, Vol. 36(5), 713-734.

Vink, Maarten P./Tirana Prokic-Breuer/Jaap Dronkers (2013). Immigrant Naturalization in the Context of Institutional Diversity: Policy Matters, but to Whom?, in: International Migration, Vol. 5I(5), I-20.

Yang, Philip Q. (1994). Explaining Immigrant Naturalisation, in: International Migration Review, Vol. 28, 449-477.

\section{Authors}

Dr. David Reichel is a sociologist and has been working as a Research Officer at the Freedoms and Justice Department of the European Union Agency for Fundamental Rights (FRA) since 20I4. Previously he was a Research Officer at the International Centre for Migration Policy Development and worked as an external lecturer at the University of Vienna.

Dr. Bernhard Perchinig is a political scientist at the International Centre for Migration Policy Development (ICMPD). He is Faculty Member at the Department for Business Law and European Integration at the Danube University Krems and at the M.A. Programme in Intercultural Studies at the University of Salzburg. 